\title{
Sick building syndrome and associated risk factors among the population of Gondar town, northwest Ethiopia
}

Haileab Belachew, Yibeltal Assefa, Gebisa Guyasa, Jember Azanaw, Tsegaye Adane, Henok Dagne and Zemichael Gizaw*

\begin{abstract}
Background: Sick building syndrome (SBS) consists of a group of mucosal, skin, and general symptoms temporally related to residential and office buildings of unclear causes. These symptoms are common in the general population. However, SBS symptoms and their contributing factors are poorly understood, and the community associates it with bad sprits. This community-based cross-sectional study was, therefore, conducted to assess the prevalence and associated factors of SBS in Gondar town.

Methods: A community-based cross-sectional study was conducted from March to April 2017. A total of 3405 study subjects were included using multistage and systematic random sampling techniques. A structured questionnaire and observational checklists were used to collect data. SBS was assessed by 24 building-related symptoms and confirmed by five SBS confirmation criteria. Multivariable binary logistic regression analysis was used to identify factors associated with SBS on the basis of adjusted odds ratio (AOR) with 95\% confidence interval (Cl) and $p<0.05$. The Hosmer and Lemeshow goodness of fit test was used to check model fitness, and variance inflation factor (VIF) was also used to test interactions between variables.

Results: The prevalence of SBS in Gondar town was $21.7 \%(95 \% \mathrm{Cl}=20.3-23.0 \%)$. Of this, the mucosal symptoms account for 64\%, the general symptoms account for 54\%, and the skin symptoms account for $10 \%$. From study participants who reported SBS symptoms, 44\% had more than one symptom. Headache (15.7\%), asthma (8.3\%), rhinitis (8.0\%), and dizziness (7.5\%) were the commonest reported symptoms. SBS was significantly associated with fungal growth in the building $[A O R=1.25,95 \% \mathrm{Cl}=(1.05,1.49)]$, unclean building $[A O R=1.26,95 \% \mathrm{Cl}=(1.03,1.55)]$, houses with no functional windows $[A O R=1.35,95 \% \mathrm{Cl}=(1.12,1.63)]$, houses with no fan $[\mathrm{AOR}=1.90,95 \% \mathrm{Cl}=(1.22,2.96)]$, utilization of charcoal as a cooking energy source $[A O R=1.40,95 \% \mathrm{Cl}=(1.02,1.91)]$, cooking inside the living quarters $[A O R=1.31,95 \% \mathrm{Cl}=(1.09,1.58)]$, and incensing and joss stick use $[\mathrm{AOR}=1.48,95 \% \mathrm{Cl}=(1.23,1.77)]$.
\end{abstract}

Conclusion: The prevalence of SBS in Gondar town was high, and significant proportion of the population had more than one SBS symptom. Headache, asthma, rhinitis, and dizziness were the commonest reported SBS symptoms. Fungal growth, cleanliness of the building, availability of functional windows, availability of fan in the living quarters, using charcoal as a cooking energy source, cooking inside the quarters, and incensing habit or joss stick use were identified as factors associated with SBS. Improving the sanitation of the living environment and housekeeping practices of the occupants is useful to minimize the prevalence of SBS.

Keywords: Sick building syndromes, Residential buildings, Building-related symptoms, Gondar town

\footnotetext{
* Correspondence: zemichael12@gmail.com

Department of Environmental and Occupational Health and Safety, Institute

of Public Health, College of Medicine and Health Sciences, University of

Gondar, Gondar, Ethiopia
}

(c) The Author(s). 2018 Open Access This article is distributed under the terms of the Creative Commons Attribution 4.0 International License (http://creativecommons.org/licenses/by/4.0/), which permits unrestricted use, distribution, and reproduction in any medium, provided you give appropriate credit to the original author(s) and the source, provide a link to the Creative Commons license, and indicate if changes were made. The Creative Commons Public Domain Dedication waiver (http://creativecommons.org/publicdomain/zero/1.0/) applies to the data made available in this article, unless otherwise stated. 


\section{Background}

Housing is one of the basic needs of a human being and fundamental for wellbeing $[1,2]$. People spend more than $90 \%$ of their time indoors [3]. Housing increasingly becomes a major public health concern. For many years, the housing environment has been acknowledged as one of the main settings that affect human health. Indoor air quality, home safety, noise, humidity and mold growth, indoor temperatures, asbestos, lead, radon, volatile organic compounds (VOC), lack of hygiene and sanitation equipment, and crowding are some of the most relevant possible health threats in dwellings [4-6].

Physical, mental, and social health is affected by the living conditions. The quality of housing conditions plays a decisive role in the health status of the residents. Many health problems are either directly or indirectly related to the building itself, because of the construction materials that were used and the equipment installed or the size or design of the individual dwellings [4, 7]. These building-related health problems are categorized in building-related diseases and sick building syndrome (SBS) [8]. SBS consists of a group of mucosal, skin, and general symptoms that are temporally related to residential and office buildings. SBS comprises a group of symptoms of unclear causes divided into mucous membrane symptoms related to the eyes, nose, throat, and dry skin, together with what are often called general symptoms of headache and lethargy [7-9].

SBS can be influenced by a variety of factors, like building-related factors (air-conditioned building, fresh air ventilation rates, indoor temperature, poor building service maintenance and cleaning, relative humidity) [7, 10-13], environmental factors and pollutants [VOCs (formaldehyde, solvents, etc.), carbon monoxide (stoves, heaters, and furnaces), dust and fibers (asbestosis, fiberglass, dirt), bio-aerosols (bacteria, molds, viruses, pollen, dust, mites, animal danders, animal excreta), trapped outdoor pollutants (vehicle or industrial exhausts), physical factors (lighting, vibration, noise, temperature, crowding, photo duplication)] [14-17], and personal factors (gender, history of being allergic, job dissatisfaction, cigarette smoke, increased use of computers) [18-22].

SBS symptoms are common in the general population. However, SBS symptoms and their contributing factors are poorly understood, especially in developing countries including Ethiopia. The community associates SBS with bad spirit. This community-based cross-sectional study was, therefore, conducted to assess prevalence and contributing factors of SBS in Gondar town.

\section{Methods}

\section{Study design and description of study settings}

A community-based cross-sectional study was conducted from March to April 2017 in Gondar town.
Gondar town is located in the northern part of Ethiopia in Amhara National Regional State, North Gondar Zone, at a distance of $747 \mathrm{~km}$ from Addis Ababa and $170 \mathrm{~km}$ from Bahirdar at $12^{\circ} 45^{\prime}$ north latitude and $37^{\circ} 45^{\prime}$ east longitudes. Gondar was founded in 1643. Based on the 2016 population estimate, Gondar had a total population of 621,168 with $3200 / \mathrm{km}^{2}$ [23].

\section{Sample size determination}

Single-population proportion formula [24] was used to determine the sample size $(n)$ with the following assumptions: $p$ (prevalence of SBS $=50 \%$, hence there are no other similar studies in Ethiopia), 95\% confidence interval (standard normal probability $=1.96$ ); $3 \%$ margin of error or maximum error to commit, $z=$ the standard normal tabulated value, and $\alpha=$ level of significance.

$$
n=\frac{\left(z_{\alpha} / 2\right)^{2} p(1-p)}{d^{2}}=\frac{(1.96)^{2} 0.5(1-0.5)}{0.03^{2}}=1068
$$

We used a design effect of 3 based on the recommendation of the Population Services International research tool kit [25] and 7\% non-response rate; the final sample became 3429 .

\section{Sampling procedures}

Multistage sampling technique was used to select study participants. Seven kebeles (the lowest administrative unit in Ethiopia) were selected from a total of 22 kebeles using simple random sampling technique. Residential buildings found in the selected kebeles were chosen using systematic random sampling technique in every seven interval. The first residential building was selected from seven houses by lottery method.

\section{Data collection procedures}

A structured questionnaire and observational checklist were used to collect data. The questionnaire was pre-tested out of the study area in a community which had similar characteristics prior to the actual data collection. Twelve graduating class environmental health students were involved in the data collection process. Training was given for the data collectors and supervisors. The data collectors visited all systematically selected households and interviewed all household members. For under-5-year-old household members, data collectors interviewed mothers or caregivers. Data collectors asked the study subjects to recall the presence of 24 SBS symptoms and related information in 3 months prior to the survey. Collectors also observed the housing and living environment condition. The overall interview process was supervised by supervisors. The collected data were checked and corrected by the data collectors immediately 
after finalizing the questionnaire before they left the house. Supervisors daily checked the completeness, quality, and consistency of information collected.

\section{Measurement of study variables}

SBS, the primary outcome variable of this study, was defined as the presence of at least one symptom associated with housing condition in the last 3 months prior to the survey. SBS was assessed by asking have you had any (or more) of the following symptoms during the last 3 months: (i) general symptoms including fatigue, headache, dizziness, reduced attention, hyperactivity, fever, chills, and eye strain; (ii) mucosal symptoms including rhinitis, nasal congestion, wheezing, asthma, dyspnea, severe lung disease, epistaxis, upper respiratory tract irritation, chest tightness, dry throat, cough, and eye irritation; and (iii) skin symptoms including skin rashes, dry or flushed facial skin, scaling/itching scalp or ears, and lip dryness [9, 26, 27]. Five criteria were used to confirm whether the symptoms are SBS or not. The criteria were as follows: (a) symptoms aggravate when staying at home, (b) symptoms either immediately or gradually disappear when leaving the house, (c) symptoms recur when returning home, (d) symptoms aggravate during the night, and (e) symptoms disappear when the room is ventilated or cleaned.

The wealth index of households was determined using principal component analysis (PCA). As health and demographic surveys (DHS) recommended, we used asset and service variables to determine the wealth index. Initially, the wealth index was classified into very poor, poor, moderate, rich, and very rich. But there was no significant difference between very poor and poor, and moderate, rich, and very rich. Based on this fact, the wealth index was classified into poor and rich. Residential buildings were taken as clean if the physical structures (floors, walls, ceilings, or roofs) have no any visible dirt, soot, spider's wrap, crack, and dampness. The living compound was taken as clean if the living environment is free from wastes, vectors, and unpleasant odor. The illumination system of the living quarters was taken as adequate if the light energy is constant, free from glare, uniformly distributed to the entire room, and suitable to perform daily activities inside without strain.

\section{Data management and statistical analysis}

Data were entered using EPI-INFO version 7 and exported into SPSS version 20 for further analysis. For most variables, data were presented by frequencies and percentages. Univariable binary logistic regression analysis was used to choose variables for the multivariable binary logistic regression analysis, variables with $p$ value less than 0.05 by the univariable analysis were then analyzed by multivariable binary logistic regression for controlling the possible effect of confounders (like age, sex, family size, economic status, and education status of the family), and finally, variables which had significant association with SBS were identified on the basis of AOR with 95\% CI and $p<0.05$. The Hosmer and Lemeshow goodness of fit test was used to check model fitness. VIF was also used to test interactions between variables.

\section{Results \\ Socio-demographic information}

A total of 964 residential buildings were visited, and a total of 3405 residents in these houses were included in this study with $99.4 \%$ response rate. One thousand eight hundred thirty-eight (54\%) study subjects were female. Three fourth, 2620 (76.9\%), of the study subjects were aged between 15 and 64 years. Nine hundred thirty-two (27.4\%) participants graduated from colleges or universities. One thousand three hundred ninety-one (40.9\%) study subjects were not engaged at the time of the survey, and 1179 (34.6\%) participants were self-employed. Two thousand twenty-three (59.4\%) study subjects were economically poor (Table 1 ).

\section{Housing condition}

The majority, 2389 (70.2\%), of the study subjects lived in houses constructed from wood and mud. One thousand seven hundred eighty (52.3\%) study subjects reported that the floor of their house is earthen floor. Two thousand eighty-six (61.3\%) study subjects said that they had only one bedroom. The majority, 3217 (94.5\%), of the study participants reported that they had no fan in their house. Nearly two thirds, 2211 (64.9\%), of the study subjects said that their residential building has no functional windows. One thousand seven hundred sixty-six (51.9\%) study subjects lived in houses in which the illumination system was not adequate. Almost all, 3317 (97.4\%), of the study participants reported that they got light from electricity. A quarter, 879 (25.8\%), of the study participants had pets in the home. Fungal growth and dampness was observed among 1462 (42.9\%) participants' house. One thousand three hundred seventy-six (40.4\%) study subjects reported that they recently used pesticides, paints, and solvents. One thousand eight hundred eighty-five (55.4\%) participants reported that cooking inside the living quarters is a common practice. One thousand three hundred twenty-seven (39\%) study subjects said that outdoor air pollutant sources (like garages, and metal and woodwork houses) were found around their home (within a 200-m radius). Incensing and utilization of a joss stick was a common habit in 1329 (39\%) participants' house. Nearly one tenth, 335 (9.8\%), of the study subjects reported that at least one of the family members smokes cigarette. The houses of 1196 (35.1\%) study 
Table 1 Socio-demographic information of study participants in Gondar town, northwest Ethiopia, March-April 2017

\begin{tabular}{|c|c|c|}
\hline Socio-demographic variables & Frequency & Percentage \\
\hline \multicolumn{3}{|l|}{ Sex } \\
\hline Male & 1567 & 46.0 \\
\hline Female & 1838 & 54.0 \\
\hline \multicolumn{3}{|l|}{ Age } \\
\hline$<15$ years & 644 & 18.9 \\
\hline $15-64$ years & 2620 & 76.9 \\
\hline$>64$ years & 141 & 4.1 \\
\hline \multicolumn{3}{|l|}{ Educational status } \\
\hline Underage & 171 & 5.0 \\
\hline Kindergarten & 123 & 3.6 \\
\hline Cannot read and write & 238 & 7.0 \\
\hline Can read and write & 439 & 12.9 \\
\hline Primary education & 589 & 17.3 \\
\hline Secondary education & 913 & 26.8 \\
\hline College or university & 932 & 27.4 \\
\hline \multicolumn{3}{|l|}{ Marital status } \\
\hline Underage & 629 & 18.5 \\
\hline Currently engaged & 1385 & 40.7 \\
\hline Currently not engaged & 1391 & 40.9 \\
\hline \multicolumn{3}{|l|}{ Occupational status } \\
\hline Underage & 82 & 2.4 \\
\hline Student & 1072 & 31.5 \\
\hline Unemployed & 220 & 6.5 \\
\hline Civil servant & 609 & 17.9 \\
\hline Self employed & 1179 & 34.6 \\
\hline Retired & 243 & 7.1 \\
\hline \multicolumn{3}{|l|}{ Economic status } \\
\hline Poor & 2023 & 59.4 \\
\hline Rich & 1382 & 40.6 \\
\hline
\end{tabular}

subjects were newly constructed (within 10 years), and the houses of 1295 (38\%) subjects were clean (Table 2).

\section{Sanitation of the living environment}

Nearly two thirds, 2192 (64.4\%), of the study participants used traditional pit latrine, and three fourths, 2600 (76.4\%), of study subjects got drinking water from an in-compound tap. Three thousand sixteen (88.6\%), 43 (1.3\%), and $1892(55.6 \%)$ of the study participants reported that they use charcoal, kerosene, and electricity, respectively, as household energy sources. A quarter, 887 (26\%), of the participants reported vector infestation in their living environment, and the living environment of 2255 (66.2\%) study subjects was clean (Table 3).

\section{Prevalence of sick building syndromes}

From a total of 3405 participants included in this study, 738 participants reported one or more symptoms associated with poor housing condition. The prevalence of SBS in Gondar town was therefore found to be $21.7 \%$ (95\% CI $=20.3-23.0 \%)$. Ninety (12.2\%) occupants who had one or more symptoms reported that the symptoms always occurred, and 648(87.8\%) occupants who had SBS said that the symptoms occurred sometimes in the last 3 months. From study participants who reported symptoms related with housing, 414 (56\%) and 324 (44\%) had one and more than one symptom/s, respectively. Four hundred seventy-four (64\%), 401 (54\%), and $72(10 \%)$ of the reported symptoms were mucosal, general, and skin symptoms, respectively. Headache, 221 (15.7\%); asthma, 116 (8.3\%); rhinitis, 112 (8.0\%); and dizziness, 106 (7.5\%), were the commonest reported symptoms (Table 4).

\section{Factors associated with sick building syndromes}

Univariable binary logistic regression was used to choose variables for the final model on the basis of $p$ values less than 0.05. Types of wall; fungal growth; cleanliness of the building; presence of functional windows; presence of fan in the quarters; cooking inside the quarters; charcoal use; habits of cigarette smoking; incensing habit and joss stick use; outdoor pollutant sources near the building; recent utilization of pesticides, paints, and solvents; and cleanliness of the living compound were variables selected for the final model. VIF was calculated considering one independent variable as the dependent variable turn by turn to test interactions between variables. The test result shows that VIF for all variables was below 3, threshold for collinearity diagnostics. This showed that there is no multicollinearity effect between independent variables.

Table 5 shows variables associated with SBS. SBS was statistically associated with fungal growth in the building. The probability of having SBS was 1.25 times higher among participants where fungal growth was observed in the building $[\mathrm{AOR}=1.25,95 \% \mathrm{CI}=(1.05,1.49)]$. This study depicted that cleanliness of buildings was significantly associated with SBS. The odds of SBS was 1.26 times higher among occupants whose building is not clean compared with their counterparts $[\mathrm{AOR}=1.26$, $95 \% \mathrm{CI}=(1.03,1.55)]$. The prevalence of SBS was 1.35 times higher among participants who lived in houses with no functional windows $[\mathrm{AOR}=1.35,95 \% \mathrm{CI}$ $=(1.12,1.63)]$. As revealed by this study, SBS was associated with utilization of fan. The probability of developing SBS was 1.90 times higher among study subjects who did not use fan $[A O R=1.90,95 \% \mathrm{CI}=(1.22,2.96)]$. This community-based study explored that SBS was associated with household cooking energy, cooking 
Table 2 Housing condition of study participants in Gondar town, northwest Ethiopia, March-April 2017

\begin{tabular}{|c|c|c|c|c|c|}
\hline & \\
\hline Housing- and sanitation-related variables & Frequency & Percentage & Housing- and sanitation-related variables & Frequency & Percentage \\
\hline Wall constructed from & & & Cigarette smoking & & \\
\hline Brick or block & 1016 & 29.8 & Yes & 335 & 9.8 \\
\hline Wood and mud & 2389 & 70.2 & No & 3070 & 90.2 \\
\hline Types of floor materials & & & Building age & & \\
\hline Earth floor & 1780 & 52.3 & New & 1196 & 35.1 \\
\hline Wood floor & 347 & 10.2 & Old & 2209 & 64.9 \\
\hline Ceramic/tiles/brick floor & 191 & 5.6 & Cleanliness of the building & & \\
\hline Cement floor & 1087 & 31.9 & Clean & 1295 & 38.0 \\
\hline Number of bedrooms & & & Not clean & 2110 & 62.0 \\
\hline
\end{tabular}

Table 2 Housing condition of study participants in Gondar town, northwest Ethiopia, March-April 2017 (Continued)
Fan is available in the quarters

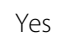

No

Functional windows

No

Yes

Illumination system of the building

\section{Adequate}

Not adequate

Light sources

Electricity

Solar cell

Candle or kuraz

Pets in the home

Yes

No

Fungal growth is observed in the building

Yes

No

Pesticides, paints, and solvents used recently

Yes

No

Cooking inside

Yes

No

1885

1520

Outdoor air pollutant sources within a 200-m radius

Yes

1327

No

2078

Incensing habit and joss stick use

Yes

1329

No
2211

1194

1639

1766

3317

79

879

2526

1462

1943

1376

2029
16.0

61.3

15.6

7.1

5.5

64.9

35.1

48.1

51.9

97.4

2.3

0.3

25.8

74.2

42.9

57.1

40.4

59.6

55.4

44.6

39.0

61.0

39.0

61.0 practice, and incensing habits of occupants. The odds of SBS was 1.4 times higher among occupants who used charcoal as cooking energy source $[\mathrm{AOR}=1.40$, $95 \% \mathrm{CI}=(1.02,1.91)]$. Occupants who cooked inside the living quarters had more chance to develop SBS $[\mathrm{AOR}=1.31,95 \% \mathrm{CI}=(1.09,1.58)]$. The probability to have SBS was 1.48 times higher among occupants

Table 3 Sanitation practices of study participants in Gondar town, northwest Ethiopia, March-April 2017

\begin{tabular}{|c|c|c|}
\hline Sanitation-related variables & Frequency & Percentage \\
\hline \multicolumn{3}{|l|}{ Toilet or latrine facilities } \\
\hline Flush toilet & 948 & 27.8 \\
\hline Traditional pit latrine & 2192 & 64.4 \\
\hline Ventilated improved pit latrine & 63 & 1.9 \\
\hline No sanitation facility & 202 & 5.9 \\
\hline \multicolumn{3}{|l|}{ Drinking water sources } \\
\hline In-residence tap & 589 & 17.3 \\
\hline In-compound tap & 2600 & 76.4 \\
\hline Out-of-compound tap & 216 & 6.3 \\
\hline \multicolumn{3}{|l|}{ Use charcoal as energy source } \\
\hline Yes & 3016 & 88.6 \\
\hline No & 389 & 11.4 \\
\hline \multicolumn{3}{|l|}{ Use kerosene as energy source } \\
\hline Yes & 43 & 1.3 \\
\hline No & 3362 & 98.7 \\
\hline \multicolumn{3}{|l|}{ Use electricity as energy source } \\
\hline Yes & 1892 & 55.6 \\
\hline No & 1513 & 44.4 \\
\hline \multicolumn{3}{|l|}{ Infestation of vectors } \\
\hline Yes & 887 & 26.0 \\
\hline No & 2518 & 74.0 \\
\hline \multicolumn{3}{|l|}{ Cleanliness of living compound } \\
\hline Clean & 2255 & 66.2 \\
\hline Not clean & 1150 & 33.8 \\
\hline
\end{tabular}


Table 4 Symptoms related with housing as reported by study participants in Gondar town, northwest Ethiopia, March-April 2017

\begin{tabular}{|c|c|c|}
\hline Symptoms & Frequency & Percentage \\
\hline \multicolumn{3}{|l|}{ General symptoms } \\
\hline Headache & 221 & 15.7 \\
\hline Dizziness & 106 & 7.5 \\
\hline Fatigue & 97 & 6.9 \\
\hline Fever & 79 & 5.6 \\
\hline Chills & 36 & 2.6 \\
\hline Hyperactivity & 34 & 2.4 \\
\hline Reduced attention & 16 & 1.1 \\
\hline Eye strain & 25 & 1.8 \\
\hline \multicolumn{3}{|l|}{ Mucosal symptoms } \\
\hline Rhinitis & 112 & 8.0 \\
\hline Nasal congestion & 92 & 6.6 \\
\hline Wheezing & 55 & 3.9 \\
\hline Asthma & 116 & 8.3 \\
\hline Dyspnea & 18 & 1.3 \\
\hline Severe lung disease & 20 & 1.4 \\
\hline Epistaxis & 91 & 6.5 \\
\hline Upper respiratory tract irritation & 10 & 0.7 \\
\hline Chest tightness & 15 & 1.1 \\
\hline Dry throat & 42 & 3.0 \\
\hline Cough & 60 & 4.3 \\
\hline Eye irritation & 69 & 4.9 \\
\hline \multicolumn{3}{|l|}{ Skin symptoms } \\
\hline Skin rashes & 23 & 1.6 \\
\hline Dry or flushed facial skin & 17 & 1.2 \\
\hline Scaling/ itching scalp or ears & 17 & 1.2 \\
\hline Lip dryness & 33 & 2.4 \\
\hline
\end{tabular}

who had a habit of incensing and using a joss stick $[\mathrm{AOR}=1.48,95 \% \mathrm{CI}=(1.23,1.77)]$.

\section{Discussion}

This study found that prevalence of SBS was 21.7\% (64\% mucosal symptoms, $54 \%$ general symptoms, and $10 \%$ skin symptoms). The prevalence of mucosal, general, and skin symptoms reported by this study is higher than the findings of other studies in China which reported mucosal symptoms (7.1\%), general symptoms (11.4\%), and skin symptoms (4.4\%) [27]. Another study in China reported lower prevalence (mucosal symptoms (35.1\%), general symptoms $(39.4 \%$,) and skin symptoms (43.4\%)) [9] compared to the current study with exception of skin symptoms. The current prevalence is lower than that report in a study in three North European cities. The prevalence reported by the later study was $30.8 \%$ (20\% mucosal, $10 \%$ general, and $8 \%$ dermal symptoms) [28].
Table 5 Factors associated with sick building syndromes among the population of Gondar town, northwest Ethiopia, March-April 2017

\begin{tabular}{|c|c|c|c|c|}
\hline \multirow[t]{2}{*}{ Variables } & \multicolumn{2}{|l|}{ SBS } & \multirow[t]{2}{*}{ COR with $95 \% \mathrm{Cl}$} & \multirow[t]{2}{*}{ AOR with $95 \% \mathrm{Cl}$} \\
\hline & Yes & No & & \\
\hline \multicolumn{5}{|c|}{ Wall constructed from } \\
\hline Brick or block & 196 & 820 & 1 & \\
\hline Wood and mud & 542 & 1847 & $1.23(1.02,1.47)$ & $1.10(0.89,1.36)$ \\
\hline \multicolumn{5}{|c|}{ Fungal growth is observed in the building } \\
\hline Yes & 362 & 1100 & $1.37(1.16,1.62)$ & $1.25(1.05,1.49)^{*}$ \\
\hline No & 376 & 1567 & 1 & \\
\hline \multicolumn{5}{|c|}{ Cleanliness of the building } \\
\hline Clean & 224 & 1071 & 1 & \\
\hline Not clean & 514 & 1596 & $1.54(1.29,1.83)$ & $1.26(1.03,1.55)^{*}$ \\
\hline \multicolumn{5}{|l|}{ Functional windows } \\
\hline Yes & 510 & 1701 & 1 & \\
\hline No & 228 & 966 & $1.27(1.07,1.51)$ & $1.35(1.12,1.63)^{* * *}$ \\
\hline \multicolumn{5}{|c|}{ Availability of fan in the quarters } \\
\hline Yes & 27 & 161 & 1 & \\
\hline No & 711 & 2506 & $1.69(1.12,2.57)$ & $1.90(1.22,2.96)^{* * *}$ \\
\hline \multicolumn{5}{|l|}{ Charcoal use } \\
\hline Yes & 684 & 2332 & $1.82(1.35,2.46)$ & $1.40(1.02,1.91)^{*}$ \\
\hline No & 54 & 335 & 1 & \\
\hline \multicolumn{5}{|l|}{ Cooking inside } \\
\hline Yes & 478 & 1407 & $1.65(1.39,1.95)$ & $1.31(1.09,1.58)^{* * *}$ \\
\hline No & 260 & 1260 & 1 & \\
\hline \multicolumn{5}{|c|}{ Family members smoke cigarette } \\
\hline Yes & 88 & 247 & $1.33(1.03,1.72)$ & $1.24(0.94,1.63)$ \\
\hline No & 650 & 2420 & 1 & \\
\hline
\end{tabular}

Incensing habit and joss stick use

$\begin{array}{lllll}\text { Yes } & 368 & 961 & 1.77(1.50,2.08) & 1.48(1.23,1.77)^{* * *} \\ \text { No } & 370 & 1706 & 1\end{array}$

Pollutant sources within the near distance

$\begin{array}{lllll}\text { Yes } & 312 & 1015 & 1.19(1.01,1.41) & 0.99(0.82,1.18) \\ \text { No } & 426 & 1652 & 1\end{array}$

Pesticides, paints, and solvents used recently

$\begin{array}{lllll}\text { Yes } & 329 & 1047 & 1.25(1.06,1.47) & 1.14(0.95,1.37) \\ \text { No } & 409 & 1620 & 1\end{array}$

Cleanliness of the compound

$\begin{array}{lllll}\text { Clean } & 444 & 1811 & 1 \\ \text { Not clean } & 294 & 856 & 1.40(1.18,1.66) & 1.16(0.96,1.40)\end{array}$

Hosmer and Lemeshow test $=0.154$ showed that the model fitted well

*Statistically significant at $p<0.05$

** Statistically significant at $p<0.01$

***Statistically significant at $p<0.001$ 
The finding of the current study is also lower than that of a study in China that reported $74.3 \%$ mucosal symptoms, $78.7 \%$ general symptoms, and $47.5 \%$ skin symptoms [29]. The variations of prevalence among different studies may be due to differences in housing and environmental conditions. Most of the houses in the current study area were substandard. The outdoor air in the settings of the other studies is polluted by industrial emissions compared with the current setting.

This study depicted that cleanliness of residential buildings was statistically associated with SBS. The prevalence of SBS was higher among occupants who lived in unclean buildings compared with occupants who lived in clean buildings. This finding is in line with the findings of other similar studies $[7,9,19,30]$. This may be due to the fact that unclean building surfaces including carpets accumulate dust and dirt, which are reservoirs for chemicals, allergens, and diseases causing pathogens [31, 32].

SBS was significantly associated with infestation of fungus or molds in the living building. Occupants who lived in buildings where fungal growth was observed reported SBS compared with their counterparts. The finding of this study is supported by other studies [7, 16, 33]. This is due to the fact that fungus or molds cause health problems in the mechanisms of either infection or allergy or toxin. Fungal spores are generally recognized as important causes of respiratory allergies [16, 34].

The current study explored that availability of functional windows is statistically associated with SBS. A wide range of literature also reported the effect of general ventilation on the health of the occupants [19, 35-37]. This fact can be explained that presence of functional windows as means of ventilating a building naturally helps the external fresh air to the living quarters and removes the internal exhausted air which in turn reduces the amount of contamination with chemicals or microorganisms, so that increased ventilation can be seen as an effective treatment of SBS [19, 37-39]. This study also revealed that availability of fan in the living quarters was significantly associated with SBS. The prevalence of SBS was higher among occupants who lived in houses with no fan. Other studies also reported similar findings $[40,41]$. This is because fan-assisted ventilation improves the quality of the indoor air $[42,43]$.

This study reported that SBS was associated with household cooking energy sources, cooking practice, and incensing habits of occupants. The prevalence of SBS was higher among occupants who used charcoal as cooking energy source. Occupants who used charcoal and cooked inside the living quarters [44-46] and who used incensing and joss stick $[27,29]$ had more chance to develop SBS. This can be justified that charcoal use and incensing habits are incomplete combustion processes that can generate gracious pollutants. Generally, cooking energy sources and cooking practices are the main sources for gracious pollutants to the indoor air $[47,48]$.

\section{Limitation of the study}

This research did not assess the condition of office buildings in this study though the condition of office buildings is a covariate for SBS associated with residential buildings. Moreover, we did not measure indoor air quality, thermal condition, and light intensity using instruments. However, we used standardized checklists to assess these parameters.

\section{Conclusion}

The prevalence of SBS in Gondar town was found to be high, and a significant proportion of the population had more than one SBS symptom. Headache, asthma, rhinitis, and dizziness were the commonest reported SBS symptoms. Fungal growth, cleanliness of the building, availability of functional windows, availability of fan in the living quarters, using charcoal as cooking energy source, cooking inside the quarters, and incensing habits or joss stick use were identified as factors associated with SBS. Improving the sanitation of the living environment and housekeeping practice of the occupants is useful to minimize the prevalence of SBS.

\section{Abbreviations \\ AOR: Adjusted odds ratio; Cl: Confidence interval; COR: Crude odds ratio; DHS: Health and demographic surveys; PCA: Principal component analysis; SBS: Sick building syndrome; SPSS: Statistical Package for Social Sciences; VIF: Variance inflation factor; VOCs: Volatile organic compounds}

\section{Acknowledgements}

The authors are pleased to acknowledge the data collectors, field supervisors, study participants, University of Gondar, and Gondar town administrators for their unreserved contributions to the success of this study.

\section{Funding}

The authors of this study did not receive funds from any funding institution. However, the University of Gondar covered questionnaire duplication and data collection fees.

\section{Availability of data and materials}

Data will be made available upon request to the primary author.

\section{Authors' contributions}

All the authors actively participated during the conception of the research issue, development of a research proposal, data collection, analysis and interpretation, and writing of various parts of the research report. HB, YA and $\mathrm{HD}$ designed the protocol and participated in data collection. ZG designed the protocol, participated in data collection, analyzed the data, supervised the overall research process, and prepared the manuscript. GG, $J A$, and TA entered data into Epi-Info epidemiological software. All the authors read and approved the final manuscript.

\section{Ethics approval and consent to participate}

Ethical clearance was obtained from the Institutional Review Board of the University of Gondar and an official letter was submitted to the town and kebeles administrators. There were no risks due to participation in this research project. The collected data were used for this research purpose only and kept with complete confidentiality. Verbal informed consent was 
obtained from the study participants and guardians for children. Researchers provided health education for the study subjects on prevention of SBS.

\section{Consent for publication}

This manuscript does not contain any individual person's data.

\section{Competing interests}

The authors declare that they have no competing interests.

\section{Publisher's Note}

Springer Nature remains neutral with regard to jurisdictional claims in published maps and institutional affiliations.

\section{Received: 7 February 2018 Accepted: 18 October 2018}

Published online: 27 October 2018

\section{References}

1. Center for disease control and prevention (CDC. ). Health related quality of life (HRQOL): the concept of well being. Available at https://www.cdc.gov/ hrqol/wellbeing.htm. Accessed on 03 Feb 2018.

2. Basic principles of healthful housing: preliminary report of the committee on hygiene of housing. Am J Public Health Nations Health. 1938;28(3):35172

3. lyagba $\mathrm{R}$. The menace of sick buildings: a challenge to all for its prevention and treatment. 2005.

4. Bonnefoy $X$. Inadequate housing and health: an overview. Int J Environ Pollut. 2007:30(3-4):411-29.

5. Krieger J, Higgins DL. Housing and health: time again for public health action. Am J Public Health. 2002:92(5):758-68.

6. Health principles of housing. World Health Organization, Geneva; 1989. ISBN 924156127 0. Available at http://apps.who.int/iris/bitstream/10665/39847/ 1/9241561270_eng.pdf. Accessed on 02 Feb 2018.

7. Burge P. Sick building syndrome. Occup Environ Med. 2004;61(2):185-90

8. Marmot A, Eley J, Stafford M, Stansfeld S, Warwick E, Marmot M. Building health: an epidemiological study of "sick building syndrome" in the Whitehall II study. Occup Environ Med. 2006;63(4):283-9.

9. Li L, Adamkiewicz G, Zhang Y, Spengler JD, Qu F, Sundell J. Effect of traffic exposure on sick building syndrome symptoms among parents/ grandparents of preschool children in Beijing, China. PLoS One. 2015;10(6): e0128767.

10. Seppänen O, Fisk WJ. Summary of human responses to ventilation. Indoor Air. 2004;14(s7):102-18

11. Fang L, Wyon D, Clausen G, Fanger PO. Sick building syndrome symptoms and performance in a field laboratory study at different levels of temperature and humidity. Indoor Air. 2002;2:466-1.

12. Bornehag C-G, Blomquist G, Gyntelberg F, Järvholm B, Malmberg P, Nordvall $L$, et al. Dampness in buildings and health. Nordic interdisciplinary review of the scientific evidence on associations between exposure to "dampness" in buildings and health effects (NORDDAMP). Indoor Air. 2001;11(2):72-86.

13. Reinikainen LM, Jaakkola JJ. Effects of temperature and humidification in the office environment. Arch Environ Health. 2001;56(4):365-8.

14. Kipen HM, Fiedler N. Environmental factors in medically unexplained symptoms and related syndromes: the evidence and the challenge. Environ Health Perspect. 2002;110(Suppl 4):597.

15. Mendell MJ, Fisk WJ, Petersen MR, Hines CJ, Dong M, Faulkner D, et al. Indoor particles and symptoms among office workers: results from a double-blind cross-over study. Epidemiology. 2002;13(3):296-304.

16. Chapman JA, Terr Al, Jacobs RL, Charlesworth EN, Bardana EJ. Toxic mold: phantom risk vs science. Ann Allergy Asthma Immunol. 2003;91(3):222-32.

17. Wargocki P, Wyon DP, Sundell J, Clausen G, Fanger P. The effects of outdoor air supply rate in an office on perceived air quality, sick building syndrome (SBS) symptoms and productivity. Indoor Air. 2000;10(4):222-36.

18. Bakó-Biró Z, Wargocki P. Weschler CJ, Fanger PO. Effects of pollution from personal computers on perceived air quality, SBS symptoms and productivity in offices. Indoor Air. 2004:14(3):178-87.

19. Gomzi M, Bobić J. SICK BUILDING SYNDROME Do we live and work in unhealthy environment? Period Biol. 2009;111(1):79-84.

20. Mizoue T, Reijula K, Andersson K. Environmental tobacco smoke exposure and overtime work as risk factors for sick building syndrome in Japan. Am J Epidemiol. 2001;154(9):803-8.
21. Brasche S, Bullinger M, Morfeld M, Gebhardt $H$, Bischof W. Why do women suffer from sick building syndrome more often than men?-subjective higher sensitivity versus objective causes. Indoor Air. 2001;11(4):217-22.

22. Ooi P, Goh K, Phoon M, Foo S, Yap H. Epidemiology of sick building syndrome and its associated risk factors in Singapore. Occup Environ Med. 1998;55(3):188-93.

23. Gondar city administration. Available at http://www.mudco.gov.et/web/ gonder/home. Accessed on 29 Jan 2018.

24. Arifin WN. Introduction to sample size calculation. Educ Med J. 2013;5(2): e89-96.

25. Capo-Chichi V, Chapman S. Sampling strategies. Population Services International. 2007; (Available at https://www.k4health.org/sites/default/files/ Sampling-Strategies-Toolkit.pdf. Accessed on 11 Oct 2018).

26. Chang $\mathrm{C}-\mathrm{J}$, Yang $\mathrm{H}-\mathrm{H}$, Wang Y-F, Li M-S. Prevalence of sick building syndrome-related symptoms among hospital workers in confined and open working spaces. Aerosol Air Qual Res. 2015;15:2378-84.

27. Wang J, Li B, Yang Q, Wang H, Norback D, Sundell J. Sick building syndrome among parents of preschool children in relation to home environment in Chongqing, China. Chin Sci Bull. 2013:58(34):4267-76.

28. Sahlberg B, Gunnbjörnsdottir M, Soon A, Jogi R, Gislason T, Wieslander G, et al. Airborne molds and bacteria, microbial volatile organic compounds (MVOC), plasticizers and formaldehyde in dwellings in three North European cities in relation to sick building syndrome (SBS). Sci Total Environ. 2013:444: 433-40.

29. Wang J, Li B, Yang Q, Yu W, Wang H, Norback D, et al. Odors and sensations of humidity and dryness in relation to sick building syndrome and home environment in Chongqing, China. PLoS One. 2013;8(8):e72385.

30. WHO Regional Office for Europe. Sick building syndrome. Available at https:// www.wondermakers.com/Portals/0/docs/ Sick\%20building\%20syndrome\%20by\%20WHO.pdf. Accessed on 01 Feb 2018.

31. Joseph G. Allen, Ari Bernstein, Xiadong Cao, Erika Sita Eitland, Skye Flanigan, Maia Gokhale, et al. The 9 foundations of a healthy building, 2017. Available at http://forhealth.org/9_Foundations_of_a_Healthy_Building.February_ 2017.pdf. Accessed on 01 Feb 2018.

32. David E. Jacobs, Rebecca Morley, Thomas Neltner, Joe Ponessa. Carpets National Center for Healthy Housing, 2008. Available at www.nchh.org/ Portals/0/Contents/CarpetsHealthyHomes.pdf. Acessed on 31 Jan 2018.

33. Straus DC. Molds, mycotoxins, and sick building syndrome. Toxicol Ind Health. 2009;25(9-10):617-35.

34. Terr Al. Sick building syndrome: is mould the cause? Med Mycol. 2009; 47(Supplement_1):S217-S22

35. Canadian Centre For Occupational Health And Safety Internet Directory(Ccohs) Indoor air quality health and safety guide. Available at: http://www.ccohs.ca/ products/publications/iaq.html. Accessed on 28 Jan 2018.

36. Ackerly K, Baker L, Brager G. Window use in mixed-mode buildings: a literature review: Center for the built environment; 2011. Available at http:// cbe.berkeley.edu/research/pdf_files/Ackerly2011-InternalReport_LitReview. pdf. Accessed on 02 Feb 2018

37. Joshi SM. The sick building syndrome. Indian J Occup Environ Med. 2008; 12(2):61.

38. Indspd Q, Lajoie $P$, Leclerc J-M, Schnebelen M. Ventilation of residential buildings: impacts on the occupants' respiratory health: summary document: Institut national de santé publique du Québec; 2007. Available at https://www.inspq.qc.ca/pdf/publications/560VentilationResidentialBuildings-Feuillet.pdf. Accessed on 02 Feb 2018

39. General ventilation in the work: guide for employers. Health and Safety Executive: 2000. ISBN 071761793 9. Available at http://www.ucu.org.uk/ media/1358/General-ventilation\%2D\%2D-guidance-for-employers-HSG202/ pdf/HSG202 - Ventilation.pdf. Accessed on 03 Feb 2018.

40. Sharma R, Balasubramanian R. Indoor human exposure to size-fractionated aerosols during the 2015 Southeast Asian smoke haze and assessment of exposure mitigation strategies. Environ Res Lett. 2017;12(11):114026.

41. Chen A, Gall ET, Chang WW. Indoor and outdoor particulate matter in primary school classrooms with fan-assisted natural ventilation in Singapore. Environ Sci Pollut Res. 2016;23(17):17613-24.

42. Awbi HB. Ventilation for good indoor air quality and energy efficiency. Energy Procedia. 2017;112:277-86.

43. Gibson's Heating \& Plumbing. How fans improve ventilation and indoor air quality, 2016. Available at https://www.gibsonsheating.com/fort-wayneindoor-air-quality/indoor-air-quality-tips-advice/item/68-how-fans-improveventilation-and-indoor-air-quality. Accessed on 03 Feb 2018. 
44. Lu C, Deng Q, Li Y, Sundell J, Norbäck D. Outdoor air pollution, meteorological conditions and indoor factors in dwellings in relation to sick building syndrome (SBS) among adults in China. Sci Total Environ. 2016;560:186-96.

45. World Health Organization (WHO). Fuel for life: household energy and health. Available at http://www.who.int/indoorair/publications/fuelforlife.pdf. Accessed on 03 Feb 2018.

46. Kulshreshtha P, Khare M. A comparative study of indoor air pollution and its respiratory impacts in Delhi, India. WIT Trans Ecol Environ. 2010;136:287-96.

47. Spiru P, Simona PL. A review on interactions between energy performance of the buildings, outdoor air pollution and the indoor air quality. Energy Procedia. 2017:128:179-86.

48. Zhang X, Chen B, Fan X. Different fuel types and heating approaches impact on the indoor air quality of rural houses in Northern China. Procedia Eng. 2015;121:493-500

Ready to submit your research? Choose BMC and benefit from:

- fast, convenient online submission

- thorough peer review by experienced researchers in your field

- rapid publication on acceptance

- support for research data, including large and complex data types

- gold Open Access which fosters wider collaboration and increased citations

- maximum visibility for your research: over $100 \mathrm{M}$ website views per year

At $\mathrm{BMC}$, research is always in progress.

Learn more biomedcentral.com/submissions 